Leigh, Oluwaseyi A.

Lecturer, Faculty of Law, OOU, Ago-Iwoye. leigh.oluwaseyi@oouagoiwoye.edu.ng

\title{
The FGN-ASUU 2009 Agreement: Implications for Constitutional Development and Labour Relations in Nigeria
}

\begin{abstract}
Agreements are usually, but not invariably the by-product of negotiations. The complex nature of man has made disputes, contentions and disagreements become second nature to human existence; and in seeking solutions to these challenges, agreements, howsoever reached - be it through concessions, conciliations or compromises - become the vehicle through which the outcome of the negotiations and bargaining are expressed. Therefore, agreements are meant to be honoured by parties who have freely made them. This represents the most fundamental basis of human existence. This article examines the FGN-ASUU 2009 Agreement and does so against the background of constitutional development and labour relations implications of the agreement. The main focus of this paper is that if industrial unrest must be checked in Nigeria, governments at all tiers must be willing to adhere to constitutional stipulations in respect of agreements reached with labour unions.
\end{abstract}

\section{Introduction}

Nigeria has had a robust history of industrial relations which dated back to the pre-independence period in the colonial times and in the course of resolving labour related disputes that have arisen in the past, negotiations have been had and agreements reached. One such agreement in the history of labour relations in Nigeria is the FGN-ASUU Agreement reached by the respective parties in 2009 after serious negotiations. ${ }^{1}$

This article proposes to examine this agreement in its entire scope and ramifications with a view to highlighting and discussing originating issues relating to the antecedents of the parties thereto.

These have been identified in this article to include, but not limited to legislative powers of the Federal Republic; appraisal of extant laws in relation to matters on the exclusive legislative list that pertain to the agreement; constitutional doctrine of "covering the field"; concept of collective bargaining which ultimately leads to collective agreements and their implications for contracts of employment. This will be undertaken with a view to highlighting and discussing potential implications that the agreement holds both for labour relations and constitutional development in Nigeria.

\section{Trade Unionism in Nigeria}

Prior to the coming into existence of the geographical entity called Nigeria and before the amalgamation of her protectorates in 1914, history had recorded the effective presence of trade unionism. Trade unions, ${ }^{2}$ which are an integral part of trade unionism have over the years bonded together to achieve common goals. Originating in Europe, trade unions became popular in many countries during the Industrial Revolution ${ }^{3}$, when the lack of skill necessary to perform most jobs shifted employment bargaining power almost completely to the employers' side, causing many workers to be mistreated and unpaid. ${ }^{4}$ Nigerian workers like their counterparts in other developing countries have witnessed phenomenal and fundamental changes in the economic and labour sector in the country.

What follows hereafter is an examination of the nature of the law regulating the relationship between a master and his servant, the role which the state played and is still playing in the shaping of the present course of labour 
development, and the part which trade unions have played and are likely to continue to play in improving the lot of the workman in the country. In carrying out this examination, much reliance will be placed on British labour practice for, except in areas of labour activities where local statutes have been enacted to regulate some aspects of the applicable common law, Nigerian labour law and a fortiori other areas of law, rest largely on the British model and many of the rules and practices which govern labour relations in Britain still give useful guidance to the practitioners in industrial relations in Nigeria. ${ }^{5}$

The historical antecedent of labour activism revealed that workers' efforts to consolidate their position usually lead to the establishment of trade unions while the corresponding effort of the state to protect workers is demonstrated in the enactment of labour laws. In developing countries where employees often have very low bargaining power, statutory provisions serve to create a floor of rights which operate as minimum terms and conditions of employment.

In many developing countries, with a common law origin, especially in Africa and Asia, contemporary labour law has evolved from old master and servant ordinances. With the growth of wage employment and Western forms of government introduced by colonial governments, a distinct labour law framework culminating in a dual system of labour regulations in many developing countries, became established, resulting in one set of laws applicable to public service employees even within the same national polity. ${ }^{6}$

Domestic attempts to address some of these challenges have led to labour law reform - the kind that is being suggested in this paper - in a number of developing countries.

The Academic Staff Union of Universities - ASUU

The Academic Staff Union of Universities - ASUU - is a trade union as defined by the Trade Unions Act. ${ }^{7}$ Being a union of workers, however, of the intellectual ${ }^{8}$ hue, history has foisted upon it, certain responsibilities that flow from that definition. ${ }^{9}$ Festus Iyayi,

An essentially union of workers, ASUU, in much the same way that a slave or a colonised could not refuse the responsibilities that followed from being defined as a slave or a colonised, cannot exercise the freedom of refusing to accept the responsibilities that its definition as workers provide ${ }^{10}$.

Although the theory of labour equality suggests that since a contract of employment rests on the common law rules of contract, the product of an agreement to hire or serve is presumed in law to be voluntary, yet in reality, the converse situation holds true as observed by an eminent jurist ${ }^{11}$

In his relationship with the employer in the employment setting, the worker is the servant, the underdog, the slave; while the employer is the master, the privileged and the slave owner. This relationship is structured in such a way that it is independent of the particular worker or employer. ${ }^{12}$ The prospective worker's only available option is either to accept the employer's terms or leave them. And a worker would rather accept unpleasant terms than have no work to go to. The employer is in a much stronger bargaining position; the dice are often heavily loaded in his favour against the worker, for it is he who dictates the terms ${ }^{13}$. As observed by a legal writer:

The employer takes responsibility for the programme of work. This implies a relation of undefined authority on the side of the employer, and undefined subordination on the side of the workman. It is a relation which inevitably gives rise to the need for guarantee against abuse, and a relation which the trade union seeks to improve ${ }^{14}$.

Hence, legislative protection had to be devised, the idea of combinations for the purpose of ameliorating the working conditions of workers had to be considered, and the power of strike has had to be invoked from time to time as this became necessary ${ }^{15}$ Akintunde Emiola.

In its dealings with members and third parties therefore, ASUU, conscious of the compelling force of history $^{16}$, chose to be "guided in its conduct by principles which are demonstrated daily in the actions the body undertakes as a union, principles which, broadly speaking inform all actions of the union in the course of history" ${ }^{\prime 17}$

\section{The FGN-ASUU 2009 Agreement}

In consonance with thespirit and letters of the Constitution of the Federal Republic of Nigeria, 1999, the immediate and highlighting features of the FGN-ASUU agreement as contained in the document titled Agreement between The Federal Government of Nigeria (FGN) and The Academic Staff Union of Universities (ASUU), January 2009, ${ }^{18}$ revealed that the composition of the representatives of the teams of the negotiating parties straddled the public universities in the country, without making a distinction between those owned by the Federal Government and those owned by the States.

From the outset of the negotiation, the FGN granted recognition for the purposes of the negotiation, to the ASUU - a trade union of whose membership comprised academic staff of public institutions irrespective of which tier of the government of the federation is the employer of the academic staff. Indeed, at all periods of the negotiation culminating in the 2009 agreement, the team leaders of ASUU who were the Presidents of the Union at different times during the period, were members of the local unions at their respective universities. ${ }^{19}$

Other members on the ASUU Re-Negotiating Team spanned public universities both at the federal and states levels. The composition also of the FGN ReNegotiation Team also revealed that its membership spanned both federal and states' universities officers. ${ }^{20}$ At the inauguration of the Committee by the then Honourable Minister of Education on behalf of the Federal 
Government of Nigeria, ${ }^{21}$ the single Term of Reference of the Committee was "to re-negotiate the 2001 FGN/ASUU Agreement and enter into a workable Agreement," ${ }^{22}$ while the essence of the re-negotiation was

(i) To reverse the decay in the University System, in order to reposition it for greater responsibilities in national development;

(ii) To reverse the brain drain, not only by enhancing the remuneration of academic staff, but also by disengaging them from the encumbrances of a unified civil service wage structure;

(iii) To restore Nigerian Universities, through massive and sustained financial intervention; and,

(iv) To ensure genuine university autonomy and academic freedom. ${ }^{23}$

It is to be observed that neither from the term of reference nor from the essence of the re-negotiation could a distinction made between federal and state universities, decipherable.

The Committee also included a group of "Advisers" comprising the Executive Secretary, National Universities Commission (NUC), Abuja (a federal institution having the statutory responsibility for regulating the affairs of Nigerian Universities), Committee of Vice Chancellors (CVC) (of public Universities) and Vice Chancellors of some federal and state universities. ${ }^{24}$ The agreement reached by the Committee was aimed at ensuring a viable university system with one rather a multiple set of academic standards. The Committee further recognised that education is on the Concurrent Legislative List in the CFRN, 1999, and by the Agreement the Federal Government did not intend and shall not compel the State Governments to implement the provisions of the Agreement in respect of their Universities, but will rather encourage the State Governments to adopt the Agreement as benchmarks, if they are to operate within the goals of achieving the same sets of academic standards for their institutions within Nigeria's University.

A humble view that will be canvassed in this paper is that considering the composition of the Committee on renegotiation which spanned representatives of both the Federal and States governments and the participation of the State Governments at the negotiation under reference, and the inclusion of the subject matters of labour and industrial relations, trade unions and pensions in the Exclusive Legislative List in the CFRN, 1999, it will be a tenuous argument on the part of states governments to seek to resile from, or refuse to give recognition to legislation enacted by the federal government made in respect of the subject matters already identified above, through the exercise of its constitutional power to:

Make laws for the peace, order and good government of the Federation or any part thereof with respect to any matter included in the Exclusive Legislative List set out in Part I of the Second Schedule to this Constitution. ${ }^{25}$

It is also on record that both tiers of government have gone ahead to implement some fundamental aspects of the agreement, such as the adoption and implementation of the agreed conditions of service of academic staff in Nigerian Universities as exemplified in the separate Salary Structure for Academic Staff in Nigerian Universities to be known as Consolidated University Academic Salary Structure II (CONUASS II) with all its components. ${ }^{26}$

Furthermore, another implementation of the Agreement, the result of which is visible on the campuses of both the federal and states universities are the various intervention funding of projects identified by "needs assessment" required by beneficiary public universities as being the identified sources of funding for tertiary education in Nigerian public universities. ${ }^{27}$

So also was the agreement for the formation of the Nigerian University Pension Fund Administrator ${ }^{28}$ and the National Health Insurance Scheme (NHIS). ${ }^{29}$

\section{Imperatives of Legislative Intervention on the FGN- ASUU 2009 Agreement}

The Re-negotiation Committee also gave prominent consideration to the twin issues of University Autonomy and Academic Freedom in accordance with objectives as set out in the various universities' enabling laws, culminating in the various amendments made to the Universities (Miscellaneous Provisions) Decree No. 11, 1993 and the Universities (Miscellaneous Provisions) (Amendment) Act, 2003 as contained and reflected in the Universities (Miscellaneous Provisions) (Amendment) Act, 2012 which provides in its Explanatory Memorandum as follows:

This Act [subsequent to the Universities
(Miscellaneous Provisions) (Amendment) Act,
2003] further amends the Universities
(Miscellaneous Provisions) Act, No. 11 of 1993
by limiting the tenure of Principal Officers to
a single term of five years, increasing the
retiring age of academic staff in the
Professorial cadre and non-academic staff in
the Universities.

Beyond the identification of the priority areas of implementation, and perhaps the machinery for implementation of the agreement, one very vital and indispensable fall out of the FGN-ASUU 2009 Agreement and which formed an integral part of the agreement - was the need by the negotiating parties for a legislative intervention for underscoring and providing legal 
imprimatur to the agreement. This therefore necessarily involves enactment of new legislation and amendment of existing ones, if any meaningful implementation would be achievable. Certain existing laws ${ }^{30}$ were identified as requiring immediate amendment and the texts for their amendments were also suggested to emphasise the urgency with which this is required. The 2009 Agreement made provision for the composition of an Implementation Committee with its prescribed membership. ${ }^{31}$

\section{Exclusiveness of Pensions Issues}

An integral part of labour relations, yet the subject matter of Pensions is separately listed as item 44 under the Exclusive Legislative List ${ }^{32}$ under the Constitution of the Federal Republic of Nigeria, 1999. In effect therefore, only the National Assembly, to the exclusion of states' legislative organs, can make laws in respect of all items under the Exclusive Legislative List. In actual fact, the relevant provisions of the Constitution put the issue beyond all doubt when it provides:

The legislative powersof the Federal Republic of Nigeria shall be vested in a National Assembly for the Federation which shall consist of a Senate and a House of Representatives. ${ }^{33}$

The National Assembly shall have power to make laws for the peace, order and good government of the Federation or any part thereof with respect to any matter included in the Exclusive Legislative List set out in Part I of the Second Schedule to this Constitution ${ }^{34}$.

Therefore, when such laws made under the provisions of section 4 are assented to by the President, pursuant to the provisions of Section 58 (3) of the Constitution, they become operative throughout the federation, (part of which Ogun State is), and the provisions of such laws become binding on all authorities and persons throughout the federation. One such law is the statute under reference, extending the retirement age of academic staff in the professorial cadres in public universities to 70 years. ${ }^{35}$

\section{Exclusiveness of Labour issues and the Trade Disputes Act provisions}

Similar to what obtains in respect of Pensions, the subject matter of Labour is also listed as item 34 under the Exclusive Legislative List in the Second Schedule to the Constitution. In effect, therefore, only the National Assembly - to the exclusion of states' legislative organs can make laws in respect of all matters connected with or pertaining to items listed under the list. In exercise of its powers as conferred by the Constitution, the National Assembly has enacted the Trade Disputes $\mathrm{Act}^{36}$.

The Trade Disputes Act made provision for the existence of labour unions and permitted such trade unions to engage in collective bargaining with their employers and reach a collective agreement which will form part of their terms of employment of the members of the Union. ${ }^{37}$
Therefore, from the signing into law of the Act extending retirement age of those academics in the professorial cadre to 70 years, the legislation becomes effective and applicable to all its intended subjects without more.

\section{The Concept of Collective Bargaining}

Collective bargaining is the process by which terms and conditions of employment are determined by negotiations between employers and trade unions. The scope of collective bargaining varies from negotiations between a single employer and a particular trade union over the terms of employment of a specified group of workers employed by that employer, to industry or service wide negotiations in which several trade unions and employers or possibly employers' associations, take part. Sector-wide collective bargaining has remained important in some areas of the public sector, although even here, there has been increased devolution of some issues to local level. Where collective bargaining takes place, the trade unions concerned are said to be 'recognised' by the employers. ${ }^{38}$ In Nigeria, the recognition of registered trade unions is a matter of statutory obligation for employers, provided that a trade union has more than one of its members in the employment of an employer. ${ }^{39}$

The substance of collective bargaining can be divided into two parts: substantive issues and procedural matters. The most important and certainly the most publicised item on bargaining agendas is pay. While collective bargaining may not determine the amount of pay that any particular worker will receive from their employer, it will normally be concerned with the pay scale for particular jobs and may determine the extent to which progression up a pay scale by any worker is automatic, subject to satisfying specified criteria or within the exercise of management discretion. Working time and any premium payments for working at specified times, such as nights or weekends, are also normally negotiated where pay is part of the collective bargaining agenda. The procedural issues determined by collective bargaining normally cover the procedure for the bargaining process itself, which may include specifying what should happen in the event of a failure to agree, for example the use of third party services such as mediation or arbitration. ${ }^{40}$ When incorporated into the contract of employment, collective agreements - which are products of collective bargaining - become enforceable between the parties to a collective agreement, which are the trade union of employees and either an employer or an association of employers. The methods of incorporation have crystallised over time into three, namely, express incorporation $^{41}$, implied incorporation ${ }^{42}$

\section{Domestication of statutes and the doctrine of "covering the field".}

Another issue, to which we now turn, is the vexed slang of "domestication" which is being stipulated as a legislative imperative by a state legislature in order to give effect to Federal laws at the State level. The theory goes on to suggest that unless and until a federal law is "domesticated" by a 
state legislature, through the process of law making such federal law cannot become applicable in such a state.

Domestication, or, to put it in the proper expression under international law, which is also referred to as 'incorporation of international law', is the process by which international agreements become part of the municipal law of a sovereign state. A country incorporates a treaty by passing domestic legislation that gives effect to the treaty in the national legal system.

Whether incorporation is necessary depends on a country's domestic law. Some states follow a monist system $^{44}$ where treaties can become law without incorporation, if their provisions are considered sufficiently self-explanatory. In contrast, dualist states $^{45}$ require all treaties to be incorporated before they can have any domestic legal effect. Most countries follow a treaty ratification method somewhere between these two extremes ${ }^{46}$.

At the national level, domestication in the context of the arguments posited by its proponents is the positive act of a state legislature to enact the provisions of the federal law on a particular subject matter - which it desires to extend to its jurisdiction - before such law can take effect within such state. This view is however contrary to the provisions of the Constitution. On the one hand, domestication only relates to international treaties as provided for under Section 12 of the Constitution of the Federal Republic of Nigeria, 1999 as follows:

No treaty ${ }^{47}$ between the Federation and any other country shall have the force of law except to the extent to which such treaty has been enacted into law by the National Assembly.

It is therefore an aberration under the Constitution to extend domestication principles to national (internal) matters and posit that where the National Assembly has made a law under the Exclusive Legislative List, such law takes effect subject to enactment by a State House of Assembly and the assent by the Governor of such a State.

Secondly, it is the humble view canvassed in this paper that even in respect of items listed under the Concurrent Legislative List - over which the State Houses of Assembly can exercise law making powers by virtue of Section 4 (7) (a-c) of the Constitution, nothing precludes the National Assembly from exercising its parallel concurrent power, as granted under and by virtue of Section 4 (4) (a) of the Constitution:

To make laws with respect to any matter in the Concurrent Legislative List set out in the first column of Part II of the Second Schedule to this Constitution to the extent prescribed in the second column opposite thereto.

The provisions highlighted above are commonly referred to as the doctrine of "covering the field" in
Constitutional Law. It is also pertinent to point out that the doctrine is a popular one in Australia and the United States. In these jurisdictions, if the Federal Legislature enacts a law on a matter in the Concurrent List, then it has "covered the field", and a State cannot thereafter enact a law that can in any way be in conflict with that federal law. By the doctrine of "covering the field", a salient feature of federal constitutional theory, and a fortiori Nigeria's federal constitution, where the federal government has validly legislated on a matter, any state legislation on the same matter which is inconsistent with the Federal Legislation will be void to the extent of the inconsistency. ${ }^{49}$ The Supreme Court has exhaustively dealt with the principles underlining the doctrine in Attorney General (Ogun State) v. Attorney General (Federation) ${ }^{50}$ and Attorney General (Ogun State) v.Aberuagba, making copious references to the doctrine of covering the field especially as being applicable in relation to exercise of the concurrent taxing powers of both the federal and states' governments.

However, Professor Nwabueze, stated in his book that the doctrine itself is of doubtful origin, and also doubted its applicability in the circumstances of the Nigerian Constitution. He stated that:

\section{...the doctrine is of doubtful constitutional validity ... the power of pre-emption implied in the doctrine of covering the field is fundamentally subversive of the purpose and spirit of concurrent power. ${ }^{52}$}

While the view expressed by the learned jurist could be persuasive as far as legislation on the concurrent list is concerned, it is proposed to respectfully distinguish the view in so far as the subject matter of pensions and labour, including trade unions, industrial relations and such like, are contained in the exclusive legislative list, then it is safe to express, extend, and insist on the sanctity of extant legislation made by the National legislature as mandatorily applicable to the twin issue of pension and labour relations even as they affect the states of the federation.

\section{Implication of the Doctrine of "Covering the Field" for Labour Mobility and Constitutionality.}

Labour mobility refers to the ease with which labourers are able to move around within an economy and between different economies. It constitutes an important factor in the study of economics because it looks at how labour, one of the major factors of production, affects growth and production. Labour mobility is of two primary types: geographic and occupational. Geographic labour mobility refers to a worker's ability to work in a particular physical location, while occupational mobility refers to a worker's ability to change job types within same geographical location..$^{53}$ According to an online dictionary resource, labour mobility means: "the degree to which people are able and willing to move from one job to another or from one area to another in order to work." 
Any attempt therefore which seeks to withhold the extension of the doctrine of "covering the field" in respect of legislation made by the Federal Government, to the federating states will be doing a serious violation to the principle of labour mobility. This is because, apart from the felt need for free labour exchanges of teaching and research personnel in the academia in public institutions, it is also a settled principle of law in labour relations, the attainment of the hallowed principle of "equal pay for equal work." All these salutary principles of labour relations will therefore be violated if 'the doctrine of covering the field' is not permitted to secure for the worker in a federating state establishment, same conditions as they obtain in a federal establishment.

A further prevention of the application of the doctrine at the federal level from being extended to the states level, will result in the perpetuation of a dual system of labour regulations, common in many developing countries, with one set of laws applicable to public service employees and another in the private sector, which is even being further stretched to the ridiculous level whereby dual set of laws will be applicable to public service employees at two levels of government respectively at the federal and the state levels.

Furthermore, it is a constitutional duty and responsibility of all organs of government and of all authorities and persons, exercising legislative or judicial powers, - as contained in the current constitution of the country - to conform to, observe and apply the provisions of the fundamental objectives and directive principles of state policy in Chapter 2 of the constitution. ${ }^{55}$ Under this chapter, the political objectives of the country are stated inter alia to ensure that adequate facilities are provided for the encouragement of free mobility of people, goods and services throughout the federation. ${ }^{56}$ While this section gives support to the labour relations principle of 'mobility of labour,' the "social objective" of the Nigerian State is stated in the Constitution to be founded on ideals of Freedom, Equality and Justice. ${ }^{57}$ A detailed breakdown of these ideals guarantees to every citizen, the opportunity for securing adequate means of livelihood, ${ }^{58}$ just and humane conditions of work, ${ }^{59}$ and equal pay for equal work without discrimination on account of sex, or on any other ground whatsoever. ${ }^{60}$ The foregoing legal submissions render tenuous therefore any suggestion that the states will need to domesticate the aspects of the agreement in a local legislation before such state can act on it or before an employee of such state can claim benefit of such aspect of the law. This is much more so, when some aspects of the agreement, such as a one-time five-year tenure of ViceChancellors, and the Consolidated University Academic Salary Structure II (CONUASS II), have been applied by both federal and states' universities without any enactment of a separate and formal legislation by state governments.

Not permitting the "benefits" of the piece of legislation enacted by the Federal Government whereby the terms and conditions of University teachers which underpin the ASUU-FGN 2009 Agreement, to percolate to the states institutions without more, can only result in an indirect unravelling of the organic law of the Nigerian state, the Constitution of the Federal Republic of Nigeria, 1999 as altered.

\section{Conclusion}

The FGN-ASUU 2009 Agreement was a product of intense, robust and solemn engagement rigorously undertaken by all relevant stakeholders in the educational sector of the country. Therefore, not being a product of hurried deliberations - having commenced in 2006 when the Re-negotiation Committee was inaugurated until 2009 when the document was executed by the principal parties' representatives - the agreement appropriated all the qualities of a document deep in its content and all-pervasive in its coverage, whose actualisation was expected to have been launched with the same sense of commitment and responsibility that attended its making.

Surprisingly however, recent happenings, occurring several years since the execution of the Agreement, indicate that the optimism of early realisation of the terms of reference, remain a forlorn hope mired in serious despair. The non-realisation of both the spirit and the letters of the agreement have been ensured by the several barricades being erected against its realisation, one of which is the untenable claim that it will require a separate, formal and fresh legislation by a willing state government before its terms can become applicable within the jurisdiction of such state. Nothing can be further from the truth on the strength of the foregoing legal submissions.

Application of the content of the agreement has been approached in a haphazard manner by both the federal and states governments, suggesting that the will to carry the agreement through is fast ebbing. Initiated by the ASUU, a body that appreciates its role as being a prescient and integral part of a larger history who by the very definition, assumes a great responsibility to act as the conscience of the society for confronting neo-colonialism and its many disguised manifestations, and accepted by the government of Nigeria, who, though may be unaware, but have placed firmly and squarely on its shoulders the responsibility of investing in human capital by re-defining education in line with the modern global trend.

All these and more are what the agreement will help the government to achieve, in order for it to take its place in the comity of nations of the world. But even now, the agreement is being observed by the government, more in its breach and thereby rendering the agreement prostrate, comatose and occasionally gasping for breath. The consequences for the option being taken, of failing to invest in education and a fortiori human capital are equally clear: an excessive degree of inequality, social immobility, and thus persistent poverty. ${ }^{61} \mathrm{~A}$ fate radically different from what the founding fathers of the nation state known as Nigeria, envisioned for it: "to help build a nation where no man is oppressed; a nation so blessed, with peace and plenty." ${ }^{62}$ 
In recent history ASUU has demonstrated rare sense of duty and consistent commitment to Nigeria and its educational system. The commitment of the struggle has spanned both civilian democracy period and military dictatorship era, from President Shagari's time through the military rule and thereafter. In 1992, the Babangida administration proscribed the ASUU, when the latter went on strike. The Union went ahead at great cost to it to win the 1992 Agreement. This agreement was defended against Abacha's attempt to kill it. When the democratic dispensation debuted under President Obasanjo, the ASUU also had to go on strike to defend the 1992 agreement and had to force the President to reach and implement the 2001 Agreement with the Union. It took three years of struggle to renegotiate the 2001 Agreement with the Musa Yar'Adua regime which culminated in the 2009 Agreement which is a continuation of ASUU's struggle for education in Nigeria. See ASUU, National Secretariat Strike Bulletin No. 11, 2013.

A trade union (British English - amalgamation is also used), labour union (Canadian English) or labour union (American English), is an organisation of workers who have bonded together to achieve common goals such as protecting the integrity of its trade, achieving higher pay, increasing the number of employees an employer hires, and better working conditions. The trade union, through its leadership bargains with the employer on behalf of union members (rank and file members) and negotiates labour contract (collective bargaining) with employers. The most common purpose of these associations or unions is 'maintaining or improving the conditions of their employment'. This may include the negotiation of wages, work rules, complaint procedures, rules governing hiring, firing and promotion of workers, benefits, workplace safety and policies. www.en.wikipedia.org/wiki/Trade union[Accessed on 21 Sep. 132013 at 00:14 am].

The Industrial revolution was the transition to new manufacturing processes in the period from about 1760 to sometime between 1820 and 1840 . This transition included going from hand to production methods to machines, new chemical manufacturing and iron production processes, improved efficiency of water power, the increasing use of steam power and the development of machine tools. It also included the change from wood and other bio-fuels to coal. It began in England and within a few decades had spread to Western Europe and the U.S. the Industrial Revolution marks a major turning point in history; almost every aspect of daily life was influenced in some way. In particular, average income and population began to exhibit unprecedented sustained growth. In the words of the Nobel Prize winner, Robert E. Lucas Jr., "For the first time in history, the living standards of the masses of ordinary people have begun to undergo sustained growth .... Nothing remotely like this economic behaviour is mentioned by the classical economists, even as a theoretical possibility". www.en.wikipedia.org/wiki/Industrial_Revolution[A ccessed on 21 September 2013 at 00:25 am].

4 The origins of unions' existence can be traced from the $18^{\text {th }}$ century where the rapid expansion of industrial society drew women, children, rural workers and immigrants to the workforce in numbers and new roles. This pool of unskilled and semi-skilled labour spontaneously organised in 'fits and starts' through-out its beginning, and would later be an important arena for the development of trade unions. www.en.wikipedia.org/wiki/Trade union[Accessed on 21 Sep. 132013 at 00:14 am].

Akintunde Emiola, Nigerian Labour Law, 1976 pp. 3-4;

Evance Kalula and Ada Ordor, "Labour Law and Trade Union Law in Developing Countries", The New Oxford Companion to Law, Peter Cane and Joanne Conaghan (eds.), Oxford University Press Inc., New York, (2008) pp.669-670.

CAP. T14 Laws of the Federation of Nigeria, 2004 defines a trade union in its section...as "any combination of workers or employers whether temporary or permanent, the purpose of which is to regulate the terms and conditions of the employment of workers".

8 Festus Iyayi, Principles of Our Union, ASUU-OOU, 2002. p.4 "ASUU is a union of intellectuals in a particular historical context of a neo-colonial, dependent and underdeveloped nation state, economy and society. In the specific African context of neocolonialism, dependency and underdevelopment, the commitment of the intellectual assumes a specific meaning. It means that the intellectual workers must practice committed scholarship by taking the side of the oppressed".

9 Festus Iyayi, op. cit., p.4 "there are however, two important qualifications that need be made to the definition of trade unions as it applies to ASUU. The first is that unlike the National Union of Road Transport Workers, ASUU is a union of intellectual workers. Being a union of intellectual workers imposes a number of obligations upon us. The first is that being workers, we are part of a larger history that not only defines us, but indicates the responsibilities that flow from that definition.... the second obligation flows from our definition as intellectuals, it means that being in a position to unearth the truth about any condition, we have the responsibility not only to pursue that truth no matter where it may lead but also, that when we find the truth, we will proclaim it and defend it. This is what is often called the commitment of the intellectual".

${ }_{10}$ Id. p. 4

1 A. A. Adeogun, "The Legal Framework of Industrial Relations in Nigeria", Nigerian Law Journal Vol. 3, 1969 p.13. "The presumption of equality between the parties...tends to ignore other social and economic considerations which may make this equality and its 
underlying fictitious and hollow.... Indeed, the socalled bargaining power of the individual worker oflittle importance in practice, especially in a country like Nigeria where there are more workmen than the jobs available and where the employer can choose freely whom to employ and under what conditions they are to be employed". See also Nordenfeldt v. Max Nordenfeldt Co. Ltd. [1894] A.C. 535 at p. 566; Fitch v. Dewes[1920], 2 Ch.159 at p. 186 (C.A.). cited in Akintunde Emiola, Nigerian Labour Law, 1976 p. 2

12 Festus Iyayi, op. cit., p.4

13 Akintunde Emiola,Nigerian Labour Law, 1976 p. 2

14 J. I. Roper, Labour Problems in West Africa,1958, Penguin, London, p.8. cited in Akintunde Emiola, Nigerian Labour Law, 1976 p. 2

15 Akintunde Emiola, op. cit.,p. 2. In Nigeria, the right to strike was exercised by the Railway-men in 1945 in the now legendary June General Strike with maximum effect but a similar protest for more wages organised by the workers of Enugu coal-mines ended in the tragic massacre of miners at Iva Valley in 1949.

16 With poor and rather brutal treatment what course is left open to the workers? In spite of the available protection, the average Nigerian was until the end of the last century, reluctant to take up paid jobs. Those who ventured to explore the uncharted sphere of wageearning employment were largely unskilled and hence unstable. The majority of the labour force consisted of the casual labourers who took time off their farming to earn some money from temporary employment, either to pay their tax or to meet their other family financial commitments. This type of employment is rooted in a day-to-day contract of service, giving rise to a category of a daily paid work-force. Thus, a large majority of the workers changed their jobs so frequently that it was difficult to evolve any meaningful industrial relations. Any idea that might have been conceived for the stabilisation of working conditions was rendered nugatory because of the uncertainty and anxiety which this created for labour management. It destroyed the basis for an organised labour movement and left in its trail economic and industrial anarchy. Akintunde Emiola, Nigerian Labour Law, 1976 pp. 2-3.

17 Festus Iyayi, op. cit.,p.5 "these principles are demonstrated daily in the actions that we undertake as a union, in the way we choose our leaders, in the qualities that we seek in our leaders, in the behaviour and practices of our leaders, in the statements of our leaders, in the bridges that we build and the groups that we interact with, in the way we conduct our meetings, in the issues that form the subject matter of our concerns and discussion, in the way we use and account for the union's funds and resources. They are also demonstrated even in the style of dress of our leaders, in the demands that we place before the government in power, in the kind of government that we advocate for, and the way that we speak about and the life that we advocate for the Nigerian people, Africans and humanity as a whole. Broadly speaking, the principles that inform all the above and other actions fall into five clusters. These are: (1). Integrity, transparency and accountability; (2). Professionalism, objectivity and hard work; (3).Courage, sacrifice and total commitment; (4). Internal democracy, teamwork and group solidarity; and (5).Patriotism, anti-imperialism and working class solidarity".

18 Agreement between The Federal Government of Nigeria (FGN) and The Academic Staff Union of U n i o o f (A S U U). www.nigeriannewsportal.com/download-full-text-ofth e - a s u u - f g - 2009 - a g r e e m e n t here/\#stshash.5qSCQ804.dpbs [Accessed on 27 August, 2016].

19 Dr. AbdullahiSule-Kano, President of ASUU was from Usman Dan Fodio University, Sokoto, and Team Leader at the negotiation table until May, 2008 when his tenure expired and Prof. Ukachukwu Awuzie, President of ASUU from Imo State University, took over as Team Leader from June, 2008.www.nigeriannewsportal.com/download-fullt ext - of - the - as u u - fg-2009-agreementhere/\#stshash.5qSCQ804.dpbs [Accessed on 27 August, 2016].

20 Id. p. 3. The Government Team Leader and Chairman, Re-Negotiation Committee was Deacon Gamaliel Onosode, Immediate Past Pro-Chancellor, University of Ibadan (a federal university). The team included Rev. Father T. E. Uwaifo, Member, was Immediate Past Pro - Chancellor, Ambrose Alli University, Ekpoma (a state university in Edo State); and Barrister Emeka Nwakpa, Member, was Former Pro-Chancellor, Abia State University, Uturu, (a state university in Abia State).

${ }^{21}$ Id. p. 2. The Honourable Minister of Education, at the time of the inauguration of the Committee on Thursday, $14^{\text {th }}$ December, 2006 was Dr. (Mrs.) Obiageli Ezekwesili.

22 www.nigeriannewsportal.com/download-full-text-of$\mathrm{th}$ e - a s u u - f g - 2009 - a g r e e m e n t here/\#stshash.5qSCQ804.dpbs [Accessed on 27 August, 2016].

23 Underline emphasis by the author.

24 Prof. Julius A. Okojie, was the then Executive Secretary of the NUC; Professors Oye Ibidapo-Obe, J. D. Amin and E. A. C. Nwanze, were at various times during the negotiation, Chairman of the CVC; while Prof. Abdullahi Mahadi, the VC of Gombe State University, Gombe was also on the list of Advisers. Agreement between The Federal Government of Nigeria (FGN) and The Academic Staff Union of Union of (ASUU). www.nigeriannewsportal.com/download-full-text-of$\mathrm{th}$ e - a s u u - f g- 2009 - a g re e m e n t here/\#stshash.5qSCQ804.dpbs [Accessed on 27 August, 2016].

25 See Section 4 (2), Constitution of the Federal Republic of Nigeria, 1999. 
26 The three components are as follows: (a) The Consolidated Salary of Academic Staff (CONUASS) approved by the Federal Government of Nigeria (FGN) effective $1^{\text {st }}$ January 2007 (FGN Circular SWC/S/04/S.309/1, dated $18^{\text {th }}$ January, 2007); (b) Consolidated Peculiar University Academic Allowances (CONPUAA), exclusively for university teaching staff and derived from allowances not adequately reflected or not consolidated in CONUASS; and, (c) Rent as approved by the FGN effective $1^{\text {st }}$ January 2007 (FGN Circular SWC/S/04/S.309/1 dated $18^{\text {th }}$ January, 2017). Agreement between The Federal Government of Nigeria (FGN) and The A c ademic Staff Union of Union of(ASUU).www.nigeriannewsportal.com/downloadfull-text-of-the-asu u-fg-2009-agreementhere/\#stshash.5qSCQ804.dpbs [Accessed on 27 August, 2016].

27 The Re-negotiation Committee, in order to arrive at the funding provisions stated under FUNDING, took serious cognisance of the widely acknowledged fact that: (i) The key to the survival of our country in the $21^{\mathrm{st}}$ Century lies in its ability to produce applied and theoretical knowledge in science, technology and humanities; and, (ii) The task of revitalising and accelerating the development of the Nigerian University System to become internationally competitive can no longer be delayed, more so if Nigeria is to become a leading economy in the world within the next ten years or so as desired by the Government. Other sources of funding identified include: (a). Federal and State Governments (a minimum of $26 \%$ of the annual budget of the State and Federal Governments be allocated to education; (b). At least $50 \%$ of the budgeted $26 \%$ shall be allocated to the universities; (c). Federal Government Assistance to States for Higher Education; (d). Education Tax Fund; (e). Petroleum Technology Development Fund (PTDF); (f). Transfer of Landed Property; (g). Patronage of University Services; (h). Funds from Alumni Association; (i). Private Sector Contributions; (j). Cost-saving Measures; (k). DutyFree importation of Educational Materials by Universities; (1). Setting up Research Development Units by Companies Operating in Nigeria; $(\mathrm{m})$. ThreeYear Rolling Plan; (n). Budget Monitoring Committee. Further incentives to enhance restoration of the Nigerian University system and industrial harmony in the universities include; (a) University Post-Doctoral Fellowship; (b) Provision for Teaching and Research Equipment; and, (c) National Research Fund. Pp. 2226.

28 For the purposes of managing the Pension Funds of University Staff, the Re-negotiation Committee recommends to the appropriate university authorities, individually or collectively to: (a) Establish a National University Pension Management Company (NUPENCO); (b) Establish a Pension Board of Trustees for each University Academic Staff Union and other staff unions; and, (c) Contract, from time to time through University Governing Councils, a group of university specific pension fund investment consultants for the purpose of advising the individual universities and NUPENCO on the most profitable investment of their Pension funds.

${ }^{29}$ It was agreed that: The University Health Centres which qualify as Primary Health Care Providers shall be recognised as such, and NHIS Contributions of University staff registered with them shall be directly remitted to the University Health Centres. University Governing Councils shall ensure that their health centres are upgraded to meet the stipulated requirements for registration set by NHIS.

30 The identified existing legislation were: Joint Admission and Matriculation Board (JAMB) Act, 2004; National Universities Commission Act, 2004; and the Education (National Minimum Standards and Establishment of Institutions) Act, 2004. For JAMB, it was agreed essentially to inter alia: (i) Provide for better collaboration between JAMB and the Universities in the process of admission of students, in a way more consistent with the autonomy of universities; (ii) Make the process of admission into universities more consistent with the powers of University Senates as provided for in the Statutes of Universities; and, (iii) To confer on universities power to admit students within the nationally recognised guidelines are followed in the process of admission. For NUC, it was agreed that the National Universities Commission Act, 2004 should be amended to make its provisions more consistent with university autonomy and powers of Senate on academic matters by deleting certain provisions from the Act; and for Education (National Minimum Standards and Establishment of Institutions) Act, it was agreed to recommend that the legislation be amended to: (i) Better articulate the coordinating function of the NUC in the accreditation exercise and the establishment of minimum standards; (ii) Provide for the accreditation of programmes through an effective collaboration of the recognised Academics, Professional and Academic Bodies with the NUC; (iii) Provide an appropriate role of University Senate in the accreditation exercise and establishment of minimum standards; and, (iv) Make the functions of Inspectors inapplicable to Universities and other Tertiary Institutions.

31 An Implementation Monitoring Committee shall consist of: (a) Two members representing the Committee of Pro-Chancellors (CPC), one of whom shall be the Chairman of CPC, The Chairman of CPC shall be the Chairman of the Committee; (b) The Chairman, Committee of Vice-Chancellors of Federal Universities (CVC); (c) One member representing the NUC as Secretary; (d) One member representing the Federal Ministry of Education; (e) Five members representing ASUU; and, (f) It is recommended that the following be members of the Committee: One representative of the Senate Committee on Education; 
One representative of the House Committee on Education; Chairman, Committee of Pro-Chancellors of State Universities; and Chairman, Committee of Vice-Chancellors of State Universities.

32 See item 44 in the Second Schedule to the Constitution of the Federal Republic of Nigeria, 1999.

33 Section 4(1), CFRN, 1999.

34 Section 4 (2), CFRN, 1999. (Emphasis in bold print by the author).

35 See Section 4,Universities (Miscellaneous Provisions) (Amendment) Act, 2012.

36 CAP T8, Laws of the Federation of Nigeria, 2004.

${ }^{37}$ Section 48 (1) (a) (b) and (2) thereof. Trade Disputes Act. Cap T8 LFN 2004.

38 Bob Simpson, "Collective Bargaining" The New Oxford Companion to Law, P. Cane and J. Conaghan (ed(s).) Oxford University Press Inc. New York, (2008) p. 153.

39 Tony Nwazuoke, "Collective Bargaining" Introduction to Nigerian Labour Law, Department of Public Law and Jurisprudence, Faculty of Law, O.O.U, Ago-Iwoye (2001) p.111. See also S. 24 (1) Trade Unions Act, CAP T14, L.F.N.2004.

$40 \quad$ Bob Simpson, op. cit. p. 154.

${ }^{41}$ Tony Nwazuoke, op. cit. p. 119. Express incorporation occurs when a contract of employment contains a provision expressly subjecting it to the terms of a collective agreement or where the employer, in issuing to his employee the statutory required particulars of terms of terms of employment, indicate in these particulars that the employee's employment contract shall be subject to some collective agreement. See National Coal Board v Galley (1958) 1 All E. R. p. 91; and Camden Exhibition and Display Ltd. v Lynott (1966) 1 Q.B. 555.

42 Id. p.121. A term of collective agreement, in the absence of express incorporation, may be implied into a contract of employment because the employer has applied or observed it for a time in respect of a group of employees of which the employee in question is a member, or, because the employee by acting on such a term had accepted to be bound, contractually. See National Coal Board v Galley (supra) and Young v Canadian Northern Railway, [1931] A. C. 83.

${ }^{43}$ Id. p. 121. Terms of a collective agreement may be made binding on employers and employees by virtue of statutory provisions. Such terms are statutorily implied into the contracts of employment of the employees concerned. See. S. 18 (1) and (3), Wages Boards and Industrial Councils Act, CAP. W1, Vol. 15 LFN. 2004.

${ }^{44}$ Monism is the philosophical view that a variety of existing things can be explained in terms of a single reality or substance. The wide definition states that all existing things go back to a source which is distinct from them. A commonly-used, restricted definition of monism asserts the presence of a unifying substance or essence. The term monism originated from Western Philosophy, and has often been applied to various legislations. www.en.wikipedia.org/wiki/Monist [Accessed on 9 February 2014]. In monist systems like the Netherlands, treaties can normally only be ratified only after they are approved by the legislature, but once this is done the treaties become legally binding in domestic law if they are self-executing. France is an example of a monist system. Under French law, ratified treaties are considered to be equivalent or even superior to domestic legislation. However, ratification must often be approved by the Parliament, especially in cases where the treaty "modifies provisions which are matters for statute". In such cases, incorporation is often either redundant or very little is required. www.en.wikipedia.org/wiki/Incorporation_of_intern ational law [Accessed on 9 February 2014].

45 Dualism (from the Latin word duo means "two") denotes a state of two parts. The term 'dualism' was originally coined to denote co-eternal binary position, a meaning that is preserved in metaphysical and philosophical duality discourse but has been diluted in other usages to indicate a system which contains two essential parts. www.en.wikipedia.org/wiki/Dualist [Accessed on 9 February 2014]. The dualist position is exemplified by the United Kingdom, where treatymaking are considered to be the exclusive competence of "Her Majesty's Government" (the executive). Hence all treaties must be incorporated if they are to have any effect on domestic legislation. To do otherwise would violate the doctrine of the sovereignty of Parliament which reserves legislative primacy to the British Parliament. www.en.wikipedia.org/wiki/Incorporation_of_intern ational law [Accessed on 9 February 2014].

46 The position of the United States is intermediate between the two extremes described above. The Supremacy Clause (VI.2) of the United States Constitution states that "all Treaties made, or which shall be made, under the authority of the United States, shall be the supreme Law of the land. However, the term "treaty" has a more restricted sense in United States Law than in international law. Of the more than 16, 000 international agreements entered into by the U.S. between 1946 and 1999, only 912 were ratified by the required two-thirds of the Senate under Article II.2.2 (the "Treaty clause") of the Constitution ("treaties" under U.S. law). The Supreme Court has also limited the direct effect of ratified treaties, notably in the case of Medellin v. Texas (2008). Hence, almost all treaties must be incorporated into U.S. federal law by Congress to have effect. www.en.wikipedia.org/wiki/Incorporation of intern ational law [Accessed on 9 February 2014].

47 "Treaty" means an agreement, league, or contract between two or more Nations or sovereigns formally signed by authorised person or persons and solemnly ratified by the several sovereigns: see Black's Law Dictionary, $6^{\text {th }}$ Edition p. 1502 , cited in Smith, I. O. The Constitution of the Federal Republic of Nigeria: 
Annotated, Lagos, 1999, p. 29.

48 The doctrine of 'covering the field' is a doctrine in constitutional theory that applies in federal constitution where legislative powers are shared between the federal government and federating states in Enumerated Lists. It applies only to legislative acts (statutes) made by the federal and state legislatures under the Concurrent Legislative List. The List of powers the doctrine operates on is the concurrent list where both tiers of government have joint interests. The doctrine originated in the U.S. and was imported into Australia where it was fully developed. In the U.S., the expression 'covering the ground' was used - Houston v. Moore 18 US 1 (1820). The doctrine simply means that where there is a conflict between the legislation of a state and the federal parliament, on a matter in the concurrent legislative list, an inconsistency arises; and as between the two so passed, the one passed by the federal parliament prevails and that of the state is rendered inoperative during the lifetime of the federal law. The reasoning behind the doctrine is that (1) it would be too presumptuous of a lower legislative body to legislate on the same subject matter as covered by the higher legislative body and (2) to subject a citizen to obedience to two laws at the same time on the same subject will be too oppressive. The basic foundation of the doctrine is that acts of the federal government in a federal system of government bind the states and their agencies as representing separate segments of the federation within the limits of the enumerated powers - Amalgamated Society of Engineers v. Adelaide Steamship Co. Ltd. (1920) 28 CLR 129, 153, 154; West v. Commissioner of Taxation (NSW) (1937) 56 CLR 657, 682. Therefore, in
Clyde Engineering Co. Ltd v. Cowburn (1926) 37 CLR 466 where a federal Act had made provisions on hours of work and a state entered upon the same field to make its own provisions, the High Court of Australia held the state law inoperative. www.tnaidike.wordpress.com/doctrine-of-coveringthe-field-in-federal-constitutional-theory/ [Accessed on 9 February 2014].

49. See Military Government, Ondo State v Adewunmi (1988) 3 NWLR (pt. 82) p. 280.

$50 \quad$ (1982) 3 N.C.L.R. 166.

51 (1985) 1 N.W.L.R. 395

52 Nwabueze, B. O. The Presidential Constitution of Nigeria, Stevens and Evans, London, 1982, p.46.

53 B rent Radcliffe, Sept. 192014. www.investopedia.com/articles/economics/09/labou r.mobility.asp [Accessed on 23 August 2016.

54 www.dictionary.cambridge.org/dictionary/english /labour-mobility [Accessed on 23 August 2016].

55 See Section 13, Constitution of the Federal Republic of Nigeria, 1999 (CFRN) (as altered).

56 See Section 15 (3) (a) CFRN, 1999.

57 See Section 17 (1) CFRN, 1999.

58 See Section 17 (3)(a) CFRN, 1999.

59 See Section 17 (3) (b) CFRN, 1999.

60 See Section 17 (3) (e) CFRN, 1999

${ }^{61}$ Ashraf Ghani and Clare Lockhart, Fixing Failed States: A Framework for Rebuilding a Fractured World, 2008, Oxford University Press, New-York, pp. 140, 142.

${ }^{62}$ An inspiring lyric in the third stanza of the former National Anthem of Nigeria, "Nigeria We Hail Thee...." adopted at her independence in 1960. 